\title{
Grape juice increases the BDNF levels but not alter the S100B levels in hippocampus and frontal cortex from male Wistar Rats
}

\author{
CAROLINE DANI ${ }^{1,2}$, ANA CRISTINA ANDREAZZA ${ }^{3}$, CARLOS ALBERTO GONÇALVES ${ }^{4}$, \\ FLÁVIO KAPIZINSKI ${ }^{4}$, JOÃO A.P. HENRIQUES ${ }^{1}$ and MIRIAN SALVADOR ${ }^{1}$ \\ ${ }^{1}$ Instituto de Biotecnologia, Universidade de Caxias do Sul/UCS, Rua Francisco \\ Getúlio Vargas, 1130, 95070-560 Caxias do Sul, RS, Brazil \\ ${ }^{2}$ Centro Universitário Metodista IPA, Rua Joaquim Pedro Salgado, 80, Rio Branco, 90420-060 Porto Alegre, RS, Brazil \\ ${ }^{3}$ Department of Psychiatry, University of Toronto, 1 King's College Circle, Toronto, ON, M5S 1A8 Canada \\ ${ }^{4}$ Universidade Federal do Rio Grande do Sul/UFRGS, Avenida Ramiro Barcelos, 2350, 90035-903 Porto Alegre, RS, Brazil
}

Manuscript received on July 13, 2016; accepted for publication on September 16, 2016

\begin{abstract}
Several studies have shown that a high consumption of vegetables and fruits is consistently associated with a low risk of oxidative stress-induced diseases, which includes some degenerative diseases such as amyotrophic lateral sclerosis, Alzheimer and Parkinson. Therefore, the objective of this study is to verify the effects of conventional and organic grape juice in the modulation of the neurotrophic factor (BDNF) and astrocytic markers protein (S100B) in hippocampus and frontal cortex of Wistar rats. In this study, 24 male Wistar rats were divided into three groups. To the first one, it was given organic purple grape juice; to the second, conventional grape juice, while the last one received only saline. After 30 days, all rats were sacrificed and hippocampus and frontal cortex were dissected. The animals that received organic and conventional grape juice showed, in frontal cortex, an elevated BNDF levels in relation to saline group. However, S100B levels did not change. These results showed that grape juices are able to modulate important marker in brain tissue, and could be an important factor to prevent brain diseases.
\end{abstract}

Key words: brain, grape juice, neuroprotection, polyphenol.

\section{INTRODUCTION}

Several studies have shown that a high consumption of vegetables and fruits is consistently associated with the protection to some important diseases (Castro et al. 2013, Mamluk et al. 2016, Mennella et al. 2016), probably by the antioxidant and anti-inflammatory properties of the polyphenolic compounds found in these fruits and vegetables

Correspondence to: Caroline Dani

E-mail: carolinedani@yahoo.com.br
(Rice-Evans and Miller 1996). Grape juice is a very rich source of polyphenols, such as flavonoids, anthocyanins, and resveratrol (Dani et al. 2007). Grape juices could be obtained from organic or conventional vineyards (Dani et al. 2007). Organic grape juice is the juice produced with grapes cultivated without pesticides or genetic engineering, certify as an organic product, while the conventional juice is produced with traditional grapes, that receive pesticides during their growth. Other studies from our group showed that purple 
grape juices, both organic and conventional, were capable to reduce the oxidative stress induced by carbon tetrachloride $\left(\mathrm{CCl}_{4}\right)$ in hippocampus, cortex, striatum and substantia nigra in rats (Dani et al. 2008), and the grape juice improved the antioxidant defense in brain damage provoked by a high fat diet (Cardozo et al. 2013). It was already demonstrated that Concord grape juice is beneficial to reverse the course of neuronal and behavioral aging in rats (Shukitt-Hale et al. 2006), and in humans this juice was capable to improve the memory and cognitive function for older adults with early memory decline (Krikorian et al. 2010) and also in older adults with mild memory decline (Krikorian et al. 2012).

BDNF is a dimer protein that plays an important role in neuroplasticity and neuronal maturation (Poo 2001, Suzuki et al. 2014) as well exert an important role in both learning and memory abilities (Binder and Scharfman 2004). It is found throughout the brain, especially in some specific regions like the hippocampus (Binder and Scharfman 2004). Indeed, by the fact that BDNF can be found peripherally, cross the blood brain barrier and have peripheral levels that present a strong correlation with the level of cerebrospinal fluid (Pan et al. 1998), this has been used as a biomarker in clinical studies. It is involved in development, maintenance and function of the central nervous system (Yamamoto et al. 1996) BDNF is the most widely distributed neurotrophic factor in the central nervous system (CNS), and performs many biological functions such as neural survival, differentiation, and plasticity (Qian et al. 2007).

$\mathrm{S} 100 \mathrm{~B}$ is a calcium binding protein physiologically produced and released mainly by astrocytes in CNS (Sorci et al. 2010). Increase in S100B may reflect either glial damage or it may belong to a body of astrocytic reactions to neural injury (Donato et al. 2013). To date, there are no study showing neuronal protection and/or modulation by the grape juices on brain-derived neurotrophic fac- tor (BDNF) and S100 calcium binding protein B (S100B) content.

The aim of this study was to evaluate whether organic and conventional purple grape juices have the ability to alter the BDNF and S100B content in frontal cortex and hippocampus.

\section{MATERIALS AND METHODS}

Twenty-four male Wistar rats (60 days-old, $200 \pm 50$ g) from our breeding colony were used in these experiments. The animals were handled under standard laboratory conditions of a 12-h light/dark cycle and fixed temperature $\left(25 \pm 2^{\circ} \mathrm{C}\right)$. Food and water were available ad libitum. All experimental procedures were performed in accordance with the NIH Guide for the Care and Use of Laboratory Animals with the approval of the local ethics committee.

The animals were randomly allocated into one of the three experimental groups ( $n=8$ per group). Group 1 served as control and received only saline, and conventional or organic purple grape juices were given to groups 2 and 3, respectively. Grape juice samples used in this study were produced from Vitis labrusca, variety Bordo, vintage 2005. The organic juices were obtained from Cooperativa Aecia (Antonio Prado, Brazil) which received the ECOVIDA certificate. ECOVIDA is a certificate to the organic agriculture, this is an associative system when there are some participants that are responsible to analyze and verify if all parameters are in accordance to the organic law. The certification will take to the company from a kind of certify organization, namely Opacs, and this organization is in accordance to the Brazilian Agriculture Ministry. The conventional juices were obtained from Vinhos Monte Reale (Flores da Cunha, RS, Brazil). Total phenolic content measured according to Singleton et al. (1999) and resveratrol and anthocyanidins amounts of the two purple grape juices were measured by HPLC and are presented in Table I. 
TABLE I

Total phenolic content and main phenolic compounds in organic and conventional grape juices.

\begin{tabular}{lcc}
\hline & Organic grape juice & Conventional grape juice \\
\hline $\begin{array}{l}\text { Total phenolic content } \\
(\mathrm{mg} \text { catechin } / \mathrm{mL})\end{array}$ & $262.50 \pm 0.70$ & $119.59 \pm 3.53^{*}$ \\
\hline Catechin $(\mathrm{ppm})$ & $33.89 \pm 1.82$ & $2.06 \pm 0.15^{*}$ \\
\hline Epicatechin $(\mathrm{ppm})$ & $2.72 \pm 0.22$ & $22.13 \pm 1.92^{*}$ \\
\hline Resveratrol amount $(\mathrm{ppm})$ & $0.213 \pm 0.005$ & $0.075 \pm 0.010^{*}$ \\
\hline Cyanidin $(\mathrm{ppm})$ & $11.79 \pm 0.42$ & $0.76 \pm 0.04^{*}$ \\
\hline Delphinidin $(\mathrm{ppm})$ & $26.30 \pm 1.15$ & $4.10 \pm 0.40^{*}$ \\
\hline Peonidin $(\mathrm{ppm})$ & $19.21 \pm 1.43$ & $8.59 \pm 0.82 *$ \\
\hline Malvidin $(\mathrm{ppm})$ & $232.46 \pm 4.25$ & $95.26 \pm 1.95^{*}$
\end{tabular}

Data are showed as media $\pm \mathrm{sd} * \mathrm{p}<0.05$ if compared between organic and conventional grape juice, analyzed by $t$ test. Data adapted from Dani et al. (2007).

The doses of grape juice were determined by calculating the average amount of juice that would be consumed daily (about $500 \mathrm{~mL}$ ) by a 70 $\mathrm{Kg}$ human person (Park et al. 2003). Juices were administered to the rats $(7 \mu$ of grape juice/g of body weight) by gavage twice a day. During the experiment, the amount was adjusted according to the animals' weight. On the $30^{\text {th }}$ day, the animals were anesthetized, and then, the animals' blood was withdrawn by cardiac puncture, kept in heparin tubes and stored at $-70^{\circ} \mathrm{C}$ until analysis.

BDNF levels in pre-frontal cortex and hippocampus were measured with sandwichELISA, using a commercial kit according to the manufacturer instructions (Chemicon, USA) (Tramontina et al. 2009). Serum S100B was measured by ELISA, as described previously (Tramontina et al. 2002). Total protein was measured by Lowry's method using bovine serum albumin as a standard (Lowry et al. 1951)

\section{RESULTS AND DISCUSSION}

BDNF modulates neuronal plasticity, inhibits cell death cascades, and increases the cell survival proteins that are responsible for the proliferation and maintenance of CNS neurons (Yuluğ et al. 2009). In this sense, we observed that both grape juices, important polyphenols sources, increased the lev- els of BDNF in frontal cortex. In hippocampus this parameter was significantly increased in the animals treated with conventional grape juice (Figure 1a). Several studies have shown that different polyphenols, including flavonoids such as genistein, quercetin, isorhamnetin (a flavonolaglycone) from Ginkgo biloba plant and acetylated flavonoid glycosides from Scopariadulcis, as well as resveratrol (the stilbenoid compound present in grapes and red wine) cause a significant enhancement of neurotrophin (nerve growth factor $[\mathrm{NGF}]$ and brain-derived neurotrophic factor [BDNF])-mediated neurite outgrowth in PC12 cells (Nakajima et al. 2011, Xu et al. 2012, Li et al. 2004, Zhang et al. 2012). Interestingly, in the hippocampus we observed that only the conventional grape juice increased the BDNF level, this result could be explained by the epicatechin level. According to the literature, several factors may influence grape juice nutritional analyses, such as grape variety, soil, climate, processing methods, etc. (Fuleki and Ricardo-da-Silva 2003). These differences could be observed in the literature, for example, Dani et al. (2007) observed that the conventional purple grape was richer in epicatechin levels than the organic one, however, Toaldo et al. (2015) showed that the organic one was richer in epicatechin level than the conventional but they analyzed grape juice from other Brazilian region and different kind of grapes. 
a

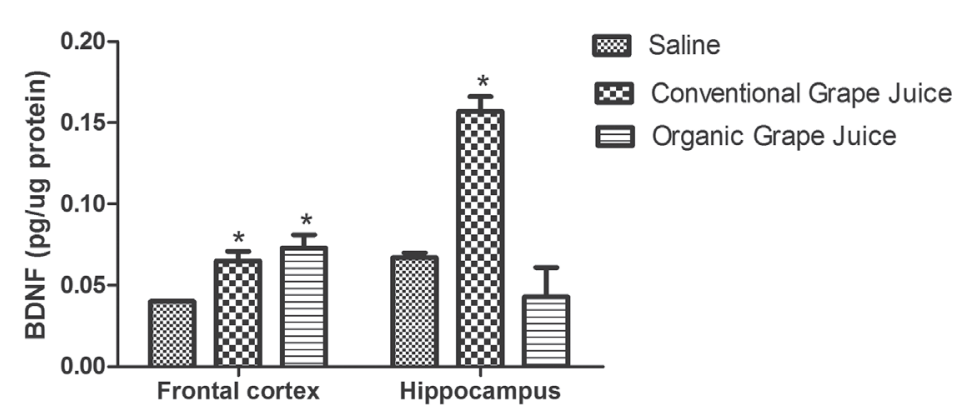

b

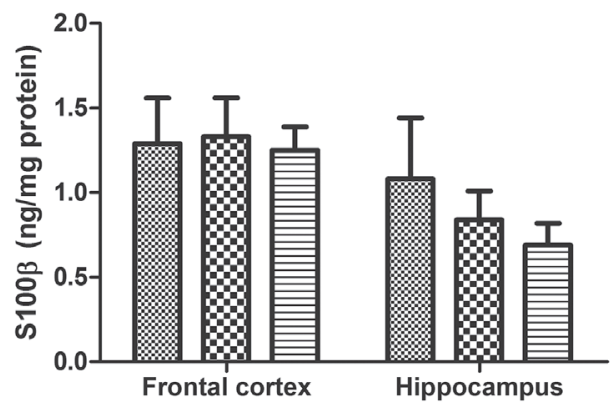

Figure 1 - BNDF (pg/ug protein) (a) and S100B content (ng/mg protein) (b) in cortex and hippocampus in rats treated with or whitout conventional grape juice (CGJ) and organic grape juice (OGJ).nData are showed as media \pm EP . $\neq$ Different letters indicate significant differences using the analysis of variance (ANOVA) and Tukey post-test $(\mathrm{p} \leq 0.05) ;{ }^{*} \mathrm{p}<0.05$ if comparing with the organic group, analyzed by t test.

The epicatechin and catechin are compounds from the flavanol group. The increase observed only by conventional grape juice, could be explained because the higher epicatechin content could represent an important effect in this neurotrophin, showing also anxiolytic and antidepressive effect in different models (Stringer et al. 2015, Lima et al. 2016). Lima et al. (2016) showed that BDNF levels in the hippocampus were increased by a polyphenols source (hydroalcoholic extract of Cocos nucifera husk fiber), suggesting an antidepressant-like effect. In this study they attributed the effect to the presence of phenols in the extract, such as epicatechin (flavonol) and chlorogenic acid. Flavonoids, a large part of polyphenols obtained from plants, are speculated to be effective in the treatment of several CNS disorders such as depression (Donato et al. 2014, Souza et al. 2013). In addition, evidence suggests that natural products rich in flavonoids, which increase the BDNF levels, are promising therapeutic targets for the treatment of depression (Stringer et al. 2015).

Van Praag et al. (2007) showed that consumption of (-)-epicatechin increases memory function, hippocampal angiogenesis, and neuronal spine density. According to this authors, some studies in humans show that (-)-epicatechin-rich foods and purified (-)-epicatechin, by cocoa beverage, showed enhanced cortical blood flow (Fisher et al. 2006,
Francis et al. 2006). According to Gage (2000) and Pereira et al. (2007), the increased cerebrovascular function, especially in the hippocampus, a brain region important for memory, may facilitate adult neurogenesis. Our results in hippocampus could be explain by Praag et al. (2007), these authors showed that the hippocampus is particularly responsive to the effects of flavanols. According to microarray analysis of gene expression in hippocampal tissue after 6 weeks of daily flavanol consumption showed that (-)-epicatechin treatment alone, without running, resulted in an upregulation (and downregulation) of genes that did not change when (-)-epicatechin was combined with running. According to this study, the expression of genes associated with learning, synaptic plasticity, and angiogenesis was increased, whereas genes relevant to learning deficits and neurodegeneration were decreased.

The S100B levels did not present differences among the groups (Figure 1b). Similar to this result, Vieira de Almeida et al. (2008) observed that in astrocytes cultures the resveratrol, an important antioxidant, did not affect basal S100B secretion, showing different results according to the treatment. However, in other study with vitamin $\mathrm{E}$, in a pathological aging mouse model, this compound was capable to increase the S100B (Bialowas-McGoey et al. 2008). The same result 
was observed in a study with (-)-epicatechin-3gallate (ECG) in C6 glioma cells. In this study ECG induces a significant improvement in glutamate uptake and S100B secretion in C6 cells, indicating that ECG could contribute to the neuroprotective role of astroglial cells (Abib et al. 2008).

Vieira de Almeida et al. (2008) observed that the S100B secretion was transiently increased (first hour) after $\mathrm{H} 2 \mathrm{O} 2$ insult, provoked probably by the oxidative damage. Conversely, when astrocytes were preincubated with resveratrol a decrease was observed in S100B secretion. When these authors incubated only with resveratrol, they observed that the resveratrol did not change S100B secretion during the first hour of insult, but induced a late increment (24 h afterwards) of extracellular levels of S100B. According to these authors, there is a limited knowledge about the mechanism of S100B secretion, as well as how the molecular signaling involved contributes to maintaining this doubt, however, they suggested that resveratrol stimulates S100B secretion, during the long-term, which, in turn, stimulates neuronal survival and activity during brain injury and recovery. This fact could explain our results, in our study we do not have a brain injury neither we tried to recover some damage, and maybe for this reason we do not see any change on S100B levels. Also, the absence of difference between the groups could be explained by the resveratrol amount. Vieira de Almeida et al. (2008) in a study with cells, and Meng et al. (2014) in a study with intraperitoneal injection in rats, showed effect in the S100B levels using almost $4.5 \mathrm{mg}$ /day of resveratrol. However, in our study the rats received almost $0.5 \mathrm{mg}$ /day by the grape juice ingestion (gavage). The amount of this polyphenol and the treatment way could explain the difference observed in these studies, and could help indicating other studies to understand better the difference.

The neuroprotection by polyphenols source has been published in the last 10 years in scientific literature. Joseph et al. (1999) showed in their study that the animals supplemented with strawberry, blueberry and spinach showed improved working memory (short-term memory). And in other study only with blueberry supplementation, the authors showed an alteration in extracellular signal regulated kinase (ERK), that may also increase hippocampal neurogenesis, suggesting that at least part of the efficacy of the blueberry supplementation may be responsible to enhancing neuronal function in areas of the brain affected by aging or disease (Casadesus et al. 2004). Recent studies showed that the grape juice was capable of improving the memory and the cognitive function in rats and humans (Shukitt-Hale et al. 2006, Krikorian et al. 2010, 2012) and also studies from our group showed an important neuroprotective action in rats that received daily purple grape juice (Dani et al. 2008, 2009, Rodrigues et al. 2012). In this way, we concluded that the grape juice, conventional and organic, could be an important alternative to promote a neuroprotection. This is the first study to show that the grape juice could increase the BDNF levels in brain, supposing that this beverage could be an alternative to improve the memory and also exert an antidepressive effect, according to the literature.

\section{ACKNOWLEDGMENTS}

The authors would like to thank the Universidade de Caxias do Sul, Coordenação de Aperfeiçoamento de Pessoal de Nível Superior (CAPES), Conselho Nacional de Desenvolvimento Científico e Tecnológico (CNPq), Fundação de Amparo à Pesquisa do Estado do Rio Grande do Sul (FAPERGS) and Instituto Brasileiro do Vinho (IBRAVIN).

\section{REFERENCES}

ABIB RT, QUINCOZES-SANTOS A, NARDIN P, WOFCHUK ST, PERRY ML, GONÇALVES CA AND GOTTFRIED C. 2008. Epicatechin gallate increases glutamate uptake and S100B secretion in C6 cell lineage. Mol Cell Biochem 310(1-2): 153-158. 
BIALOWAS-MCGOEY LA, LESICKA A AND WHITAKER-AZMITIA PM. 2008. Vitamin E increases S100B-mediated microglial activation in an S100Boverexpressing mouse model of pathological aging. Glia 56(16): 1780-1790.

BINDER DK AND SCHARFMAN HE. 2004. Brain-derived neurotrophic factor. Growth Factors 22(3): 123-131.

CARDOZO MG, MEDEIROS N, LACERDA DDOS S, DE ALMEIDA DC, HENRIQUES JA, DANI C AND FUNCHAL C. 2013. Effect of chronic treatment with conventional and organic purple grape juices (Vitis labrusca) on rats fed with high-fat diet. Cell Mol Neurobiol 33(8): 1123-1133.

CASADESUS G, SHUKITT-HALE B, STELLWAGEN HM, ZHU X, LEE HG, SMITH MA AND JOSEPH JA. 2004. Modulation of hippocampal plasticity and cognitive behavior by short-term blueberry supplementation in aged rats. Nutr Neurosci 7(5-6): 309-316.

CASTRO DC, SAMUELS M AND HARMAN AE. 2013. Growing healthy kids: a community garden-based obesity prevention program. Am J Prev Med 44(3 Suppl 3): S193-S199.

DANI C, OLIBONI LS, UMEZU FM, PASQUALI MA, SALVADOR M, MOREIRA JC AND HENRIQUES JA. 2009. Antioxidant and Antigenotoxic Activities of Purple Grape Juice-Organic and Conventional - in Adult Rats. J Med Food 12: 1111-1118.

DANI C, OLIBONI LS, VANDERLINDE R, BONATTO D, SALVADOR M AND HENRIQUES JAP. 2007. Phenolic content and antioxidant activities of white and purple juices manufactured with organically- or conventionally-produced grapes. Food Chem Toxicol 45: 2574-2580.

DANI C, PASQUALI MA, OLIVEIRA MR, UMEZU FM, SALVADOR M, HENRIQUES JAP AND MOREIRA JC. 2008. Protective effects of purple grape juice on carbon tetrachloride-induced oxidative stress in brains of adults Wistar rats. J Med Food 11: 55-61.

DONATO R, CANNON BR, SORCI G, RIUZZI F, HSU K, WEBER DJ AND GECZY CL. 2013. Functions of S100 proteins. Curr Mol Med 13(1): 24-57.

DONATO F, DE GOMES M, GOES A, FILHO C, DEL FABBRO L, ANTUNES M, SOUZA L, BOEIRA S AND JESSE C. 2014. Hesperidin exerts antidepressantlike effects in acute and chronic treatments in mice: possible role of L-arginine-NO-cGMP pathway and BDNF levels. Brain Res Bull 104: 19-26.

FISHER ND, SOROND FA AND HOLLENBERG NK. 2006. Cocoa flavanols and brain perfusion. J Cardiovasc Pharmacol 47: S210-S214.

FRANCIS ST, HEAD K, MORRIS PG AND MACDONALD IA. 2006. The effect of flavanol-rich cocoa on the fMRI response to a cognitive task in healthy young people. J Cardiovasc Pharmacol 47: S215-S220.
FULEKI T AND RICARDO-DA-SILVA JM. 2003. Effects of cultivar and processing method on the contents of catechins and procyanidins in grape juice. J Agric Food Chem 51: 640-646.

GAGE FH. 2000. Mammalian neural stem cells. Science 287: 1433-1438.

JOSEPH JA, SHUKITT-HALE B, DENISOVA NA, BIELINSKI D, MARTIN A, MCEWEN JJ AND BICKFORD PC. 1999. Reversals of age-related declines in neuronal signal transduction, cognitive, and motor behavioral deficits with blueberry, spinach, or strawberry dietary supplementation. J Neurosci 19(18): 8114-8121.

KRIKORIAN R, BOESPFLUG EL, FLECK DE, STEIN AL, WIGHTMAN JD, SHIDLER MD AND SADAT-HOSSIENY S. 2012. Concord Grape Juice Supplementation and Neurocognitive Function in Human Aging. J Agric Food Chem 60(23): 5736-5742.

KRIKORIAN R, SHIDLER MD, NASH TA, KALT W, VINQVIST-TYMCHUK MR, SHUKITT-HALE B AND JOSEPH JA. 2010. Blueberry supplementation improves memory in older adults J Agric Food Chem 58(7): 3996-4000.

LI Y, CHEN X, SATAKE M, OSHIMA Y AND OHIZUMI Y. 2004. Acetylated flavonoid glycosides potentiating NGF action from scoparia dulcis. J Nat Prod 67(4): 725727.

LIMA EB ET AL. 2016. Antidepressant, antioxidant and neurotrophic properties of the standardized extract of Cocos nucifera husk fiber in mice. J Nat Med 70(3): 510-521.

LOWRY OH, ROSEBROUGH NJ, FARR AL AND RANDALL RJ. 1951. Protein measurement with the Folin phenol reagent. J Biol Chem 193: 265-267.

MENG XJ, WANG F AND LI CK. 2014. Resveratrol is Neuroprotective and Improves Cognition in Pentylenetetrazole-kindling Model of Epilepsy in Rats. Indian J Pharm Sci 76(2): 125-131.

MAMLUK L, O'DOHERTY MG, ORFANOS P, SAITAKIS G, WOODSIDE JV, LIAO LM, SINHA R, BOFFETTA P, TRICHOPOULOU A AND KEE F. 2016. Fruit and vegetable intake and risk of incident of type 2 diabetes: results from the consortium on health and ageing network of cohorts in Europe and the United States (CHANCES). Eur J Clin Nutr 71(1): 83-91.

MENNELLA JA, REITER AR AND DANIELS LM. 2016. Vegetable and Fruit Acceptance during Infancy: Impact of Ontogeny, Genetics, and Early Experiences. Adv Nutr 7(1): 211S-219S.

NAKAJIMA K-I, NIISATO N AND MARUNAKA Y. 2011. Genistein enhances the NGF-induced neurite outgrowth. Biomed Res 32(5): 351-356.

PAN W, BANKS WA, FASOLD MB, BLUTH J AND KASTIN AJ. 1998. Transport of brain-derived neurotrophic factor across the blood-brain barrier. Neuropharmacology 37(12): 1553-1561. 
PARK YK, PARK E, KIM JS AND KANG. 2003. Daily grape juice consumption reduces oxidative DNA damage and plasma free radical levels in healthy koreans. Mutat Res 529: 77-86.

PEREIRA AC, HUDDLESTON DE, BRICKMAN AM, SOSUNOV AA, HEN R, MCKHANN GM, SLOAN R, GAGE FH, BROWN TR AND SMALL SA. 2007. An in vivo correlate of exercise-induced neurogenesis in the adult dentate gyrus. Proc Natl Acad Sci USA 104: 56385643.

POO MM. 2001. Neurotrophins as synaptic modulators. Nat Rev Neurosci 2(1): 24-32.

QIAN L, ZHAO J, SHI Y, ZHAO X, FENG G, XU F, ZHU S AND HE L. 2007. Brain-derived neurotrophic factor and risk of schizophrenia: an association study and metaanalysis. Biochem Biophys Res Commun 16; 353(3): 738743.

RICE-EVANS CA AND MILLER NJ. 1996. Antioxidant activities of flavonoids as bioactive components of food. Biochem Soc Trans 24(3): 790-795.

RODRIGUES AD ET AL. 2012. Neuroprotective and anticonvulsant effects of organic and conventional purple grape juices on seizures in Wistar rats induced by pentylenetetrazole. Neurochem Int 60(8): 799-805.

SHUKITT-HALE B, CAREY ABS, SIMON LBA, MARK DA AND JOSEPH JA. 2006. Effects of Concord grape juice on cognitive and motor deficits in aging. Nutrition 22: $295-302$.

SINGLETON VL, ORTHOFER R AND LAMUELARAVENTOS RM. 1999. Analysis of total phenols and other oxidation substrates and antioxidants by means of Folin-Ciocalteau reagent. In: Packer L (Ed), Methods in enzymology, oxidant and antioxidants, 541 Part A ed. San Diego: Academic Press, p. 159-178.

SORCI G, BIANCHI R, RIUZZI F, TUBARO C, ARCURI C, GIAMBANCO I AND DONATO R. 2010. S100B protein, a damage-associated molecular pattern protein in the brain and heart, and beyond. Cardiovasc Psychiatry Neurol 2010: ID 656481, p. 1-13.

SOUZA L, DE GOMES M, GOES A, DEL FABBRO L, FILHO C, BOEIRA S AND JESSE C. 2013. Evidence for the involvement of the serotonergic 5-HT1A receptors in the antidepressant-like effect caused by hesperidin in mice. Prog Neuropsychopharmacol 40: 103-109.

STRINGER TP, GUERRIERI D, VIVAR C AND VAN PRAAG H. 2015. Plant-derived flavanol (-) epicatechin mitigates anxiety in association with elevated hippocampal monoamine and BDNF levels, but does not influence pattern separation in mice. Transl Psychiatry 5(1): e493, p. $1-9$.

SUZUKI G, TOKUNO S, NIBUYA M, ISHIDA T, YAMAMOTO T, MUKAI Y, MITANI K, TSUMATORI G, SCOTT D AND SHIMIZU K. 2014. Decreased plasma brain-derived neurotrophic factor and vascular endothelial growth factor concentrations during military training. PLoS One 9(2): e89455, p. 1-8.

TOALDO IM, CRUZ FA, ALVES T DE L, DE GOIS JS, BORGES DL, CUNHA HP, DA SILVA EL AND BORDIGNON-LUIZ MT. 2015. Bioactive potential of Vitis labrusca L. grape juices from the Southern Region of Brazil: phenolic and elemental composition and effect on lipid peroxidation in healthy subjects. Food Chem 173: 527-535.

TRAMONTINA F, CONTE S, GONÇALVES D, GOTTFRIED C, PORTELA LV, VINADE L, SALBEGO C AND GONÇALVES CA. 2002. Developmental changes in S100B content in brain tissue, cerebrospinal fluid, and astrocyte cultures of rats. Cell Mol Neurobiol 22(3): 373-378.

TRAMONTINA JF, ANDREAZZA AC, SANT'ANNA MK, STERTZ L, GOI J, CHIARANI F AND KAPCZINSKI F. 2009. Brain-derived neurotrophic factor serum levels before and after treatment for acute mania. Neurosci Lette 452(13): 111-113.

VAN PRAAG H, LUCERO MJ, YEO GW, STECKER K, HEIVAND N, ZHAO C, YIP E, AFANADOR M, SCHROETER H, HAMMERSTONE J AND GAGE FH. 2007. Plant-derived flavanol (-) epicatechin enhances angiogenesis and retention of spatial memory in mice. $\mathrm{J}$ Neurosci 27(22): 5869-5878.

VIEIRA DE ALMEIDA LM, PIÑEIRO CC, LEITE MC, BROLESE G, LEAL RB, GOTTFRIED C AND GONÇALVES CA. 2008. Protective effects of resveratrol on hydrogen peroxide induced toxicity in primary cortical astrocyte cultures. Neurochem Res 33(1): 8-15.

XU SL, CHOI RC, ZHU KY, LEUNG KW, GUO AJ, BI D, XU H, LAU DT, DONG TT AND TSIM KW. 2012. Isorhamnetin, a flavonol aglycone from Ginkgo biloba L., induces neuronal differentiation of cultured PC12 cells: potentiating the effect of nerve growth factor. Evid Based Complement Alternat Med 2012: ID 278273, p. 1-11.

YAMAMOTO M, SOBUE G, YAMAMOTO K, TERAO S AND MITSUMA T. 1996. Expression of mRNAs for neurotrophic factors (NGF, BDNF, NT-3, and GDNF) and their receptors (p75NGFR, trkA, trkB, and trkC) in the adult human peripheral nervous system and nonneural tissues. Neurochem Res 21(8): 929-938.

YULUĞ B, OZAN E, GÖNÜL A AND KILIC E. 2009. Brain-derived neurotrophic factor, stress and depression: a mini-review. Brain Res Bull 78: 267-269.

ZHANG F, WANG YY, LIU H, LU YF, WU Q, LIU J AND SHI JS. 2012. Resveratrol produces neurotrophic effects on cultured dopaminergic neurons through prompting astroglial BDNF and GDNF release. Evid Based Complement Alternat Med 2012: ID 937605, p. 1-7. 
